\title{
Determination and discrimination in characteristics of coastal habitats in some parts of 'Bhal' region
}

\author{
Suhas J. Vyas ${ }^{1, *}$, A. J. Joshi ${ }^{2}$ \\ ${ }^{1}$ Department of Earth \& Environmental Science, K.S.K.V. Kachchh University, \\ Bhuj- Kachchh, India \\ ${ }^{2}$ Department of Life Science, Bhavnagar University, Bhavnagar, India \\ *E-mail address: vsuhas_13@yahoo.co.in
}

\begin{abstract}
Gujarat has a coast line of approximately $1700 \mathrm{Km}$, varying in different habitat conditions. The state has two gulfs viz., gulf of Khambhat and gulf of Kachchh. Edaphic conditions of different habitats in 'Bhal' region of Gujarat state which falls in two districts viz. Ahmedabad and Bhavnagar district of Gujarat state. The coastal vegetation depends on the edaphic conditions of the region. The coastal flora of the 'Bhal' region belonging to Bhavnagar district has species like Suaeda nudiflora, Prosopis chilensis, Dichanthium annulatum, etc. The 'Bhal' region has marshy, wetland and semiarid habitat. The present study investigates different physico-chemical parameters like Electrical Conductivity, $\mathrm{pH}$ and Sodium Adsorption Ratio, as well as mineral ion Sodium, Potassium, Calcium, Magnessium and Chloride concentration in the soil of 'Bhal' region.
\end{abstract}

Keywords: 'Bhal' region; soil habitat; marshy; freshwater; semi-arid; mineral ions

\section{INTRODUCTION}

'Bhal' region is situated on the south-west border of Saurashtra, spreading in 2 revenue districts of Bhavnagar and Ahmedabad on the left border of the Gulf of Khambhat (Cambay). The term 'Bhal' in Sanskrit language means a forehead and as the hairs do not grow on the forehead, the natives here believe, plant species find difficult to grow in this area. In fact, it is an ecologically complex coastal belt having length of approximately $100 \mathrm{~km}$ and breadth of $25 \mathrm{~km}$ and low mean sea level; it receives an average annual rainfall about 650 to $700 \mathrm{~mm}$ and includes moderately big mouths of the rivers Sabarmati, Bhogavo and Bhadar and smaller ones of Keri, Ghelo and Kalubhar rivers. This region can be classified as a $\sim 15 \mathrm{kms}$ wide coastal wetland comprising of marshy areas towards the Gulf of Khambhat and of freshwater bodies in a landward margin of $\sim 10 \mathrm{kms}$, which remains flooded during monsoon. Because of this diversified edaphic conditions, the flora represents a combination of salt tolerant halophytes growing in marshy area, less salt tolerant species and aquatic plants occurring in inland areas.

This investigation differentiates habitats of 'Bhal' region near gulf of Khambhat. Coastal wetlands represent interesting localities, which are influenced by tidal waters and freshwaters of the rivers. Freshwater condition is more prominent during the monsoon because of precipitation. Such habitats support plant communities adapted to varying degree 
of salt tolerance, much remains to be done on biodiversity and phytosociology of such specialize group of plants. The present study shows the characteristics of soil conditions of different habitats found in this part of the country near the gulf.

\section{MATERIALS \& METHODS}

Soil samples $(0-15 \mathrm{~cm})$ collected from each twin belt transect supporting halophytes, were sun dried, powdered and passed through 20 -mesh sieve before analysis.

$100 \mathrm{~g}$ of soil sample was taken in a conical flask and $200 \mathrm{ml}$ of distilled water was added to prepare (1:2) soil : water suspension (Chopra and Kanwar, 1991). The suspension was thoroughly shaken and kept overnight. The solution was filtered and the filtrate was made up to $250 \mathrm{ml}$ for further analysis. Electrical conductivity of 1:2 extracts was measured on EC meter (model WTW LF 530, 1983, West Germany), and pH on pH meter (Elico, model LI-120). Flame Photometer (Elico, model-128) was used for the estimation of sodium $\left(\mathrm{Na}^{+}\right)$and potassium $\left(\mathrm{K}^{+}\right)$. Calcium $\left(\mathrm{Ca}^{2+}\right)$ and magnesium $\left(\mathrm{Mg}^{2+}\right)$ were estimated by EDTA (ethylene diamine tetra acetic acid) method (Vogel, 1978). Chloride $\left(\mathrm{Cl}^{-}\right)$was estimated by argentometric method (APHA, 2005).

\section{Study area:}

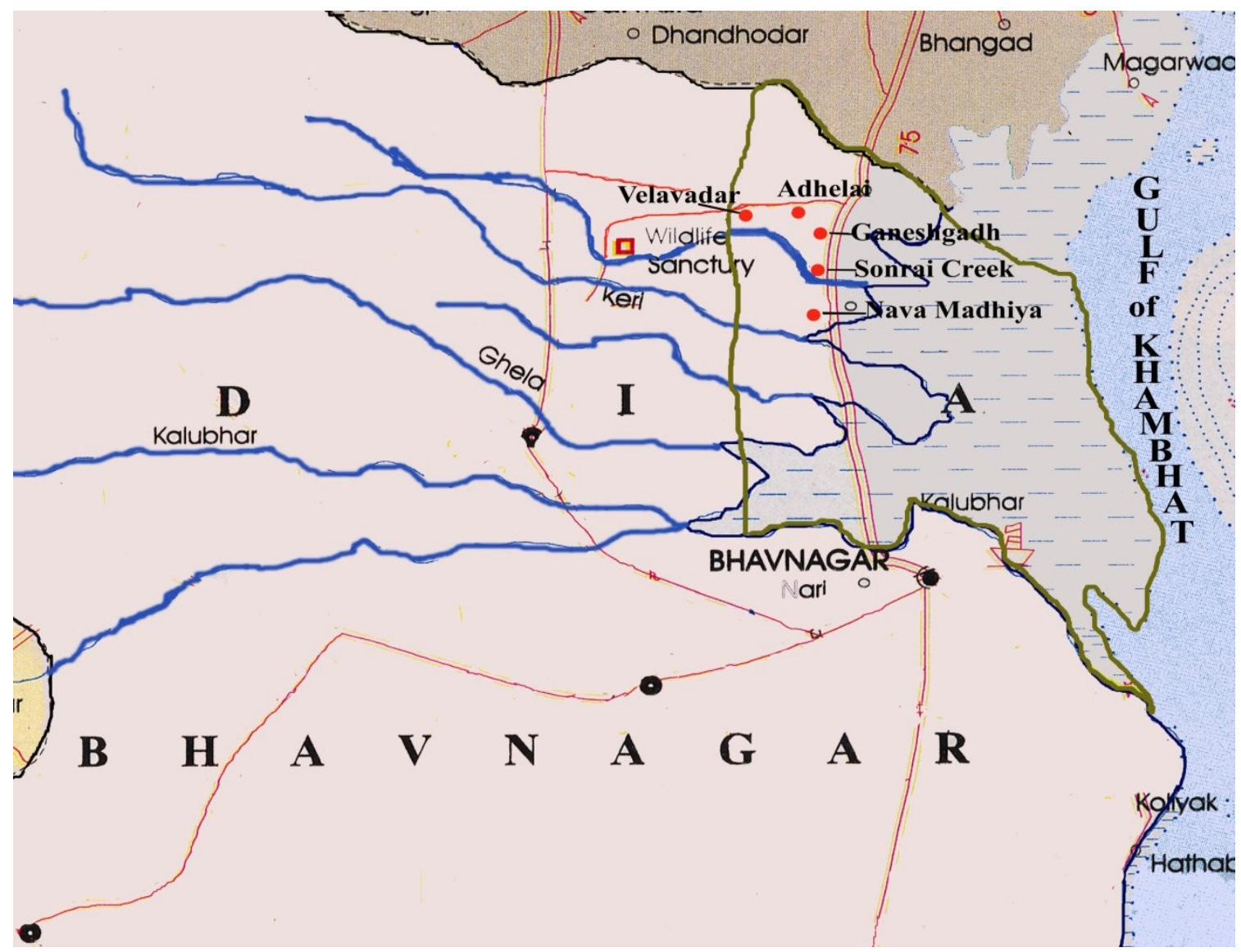




\section{RESULTS}

Coastal habitats feature a combination of chemical transformations and chemical transport not shared by many other ecosystems. Results of physico-chemical analysis of 5 locations supporting 6 plant species at marshy, freshwater and dry inland saline habitats are presented in this section. Soil samples were collected in month of September (monsoon); December (winter) and May (summer). Results of these samples were considered for seasonal variations. Ionic concentrations are expressed in terms of meq. in (1:2) soil : water extracts of $100 \mathrm{~g}$ soil throughout this study.

\section{Location 1. Nava Madhiya}

This habitat remains flooded either by mixed waters during monsoon or by high tidal waters during the rest of the year. Only one succulent species Suaeda nudiflora Moq. grew here. Electrical conductivity (salinity) of soil samples collected from the 3 twin belt transects laid down during three seasons at this location fluctuated from 25.427 to $57.267 \mathrm{dS} \cdot \mathrm{m}^{-1}$ (Table 1), whereas $\mathrm{pH}$ and SAR varied between 7.00 to 7.94 and 11.91 to 15.08 , respectively. Amount of $\mathrm{Cl}^{-}\left(24.037\right.$ to $\left.173.943 \mathrm{meq} \cdot \mathrm{g}^{-100}\right)$ was greater than that of $\mathrm{Na}^{+}$, which ranged between 9.533 to $30.437 \mathrm{meq} \cdot \mathrm{g}^{-100}$. These results also showed greater concentrations of $\mathrm{Mg}^{2+}$ ( 0.703 to $\left.9.513 \mathrm{meq} \cdot \mathrm{g}^{-100}\right)$ than that of $\mathrm{Ca}^{2+}\left(0.5\right.$ to $\left.4.15 \mathrm{meq} \cdot \mathrm{g}^{-100}\right) . \mathrm{K}^{+}$was found in low concentration $\left(0.37\right.$ to $\left.2.827 \mathrm{meq} \cdot \mathrm{g}^{-100}\right)$.

These results primarily indicated high values of salinity (EC), $\mathrm{pH}$ and SAR during summer. Likewise, the data of inorganic ions clearly reflected their greater concentrations in summer than either in monsoon or winter. Thus, this habitat was exposed to subtropical climatic variations.

Fig. 1. Ions in soil at Navamadiya location.

Table 1. Physico-chemical parameters at Navamadahiya location.

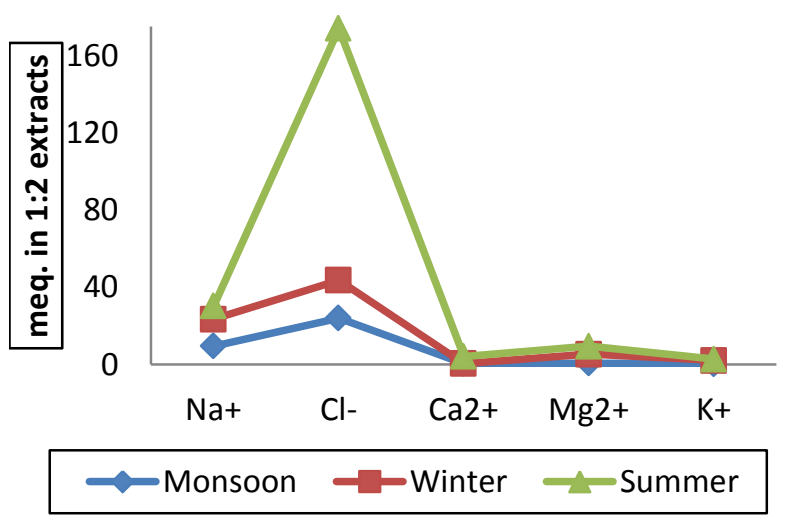

\begin{tabular}{|c|c|c|c|}
\hline & EC $\left(\mathbf{d S} \cdot \mathbf{m}^{-\mathbf{1}}\right)$ & $\mathbf{p H}$ & SAR \\
\hline Monsoon & 25.427 & 7.237 & 12.15 \\
\hline Winter & 36.637 & 7.007 & 15.08 \\
\hline Summer & 57.267 & 7.94 & 11.91 \\
\hline
\end{tabular}

\section{Location 2. Sonrai Creek}

Sonrai creek is a marshy location, wherein one succulent $S$. nudiflora and one nonsucculent Aeluropus lagopoides, Trin. halophytic species occurred. Analysis of soil samples collected from 3 twin belt transects laid down at this location indicated the electrical conductivity varying between 18.72 to $42.51 \mathrm{dS} \cdot \mathrm{m}^{-1}$ (Table 2). $\mathrm{pH}$ fluctuated from 7.04 to 7.80 and SAR from 8.74 to 18.96. These findings suggested dominance of $\mathrm{Na}^{+}$and $\mathrm{Cl}^{-}$ ranging between 5.92 to $37.67 \mathrm{meq} \cdot \mathrm{g}^{-100}$ and 14.23 to $89.90 \mathrm{meq} \cdot \mathrm{g}^{-100}$, respectively (Fig. 2). 
$\mathrm{Ca}^{2+}$ and $\mathrm{Mg}^{2+}$ varied between 0.49 to $3.277 \mathrm{meq} \cdot \mathrm{g}^{-100}$. Concentrations of $\mathrm{K}^{+}$were observed between 0.363 to $3.05 \mathrm{meq} \cdot \mathrm{g}^{-100}$. These results collectively reflected maximum values of EC, $\mathrm{pH}$ and SAR and all inorganic ions either in winter or summer at location 2.

Fig. 2. Ions in soil at sonrai creek location.

Table 2. Physico-chemical parameters at sonrai creek location.

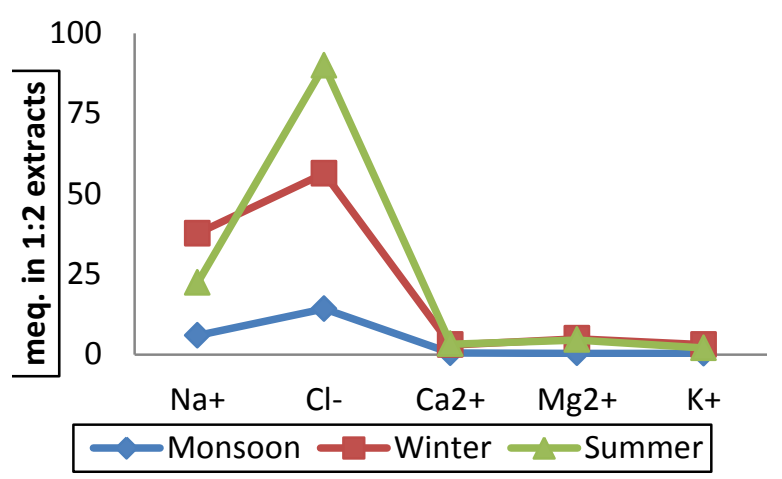

\begin{tabular}{|c|c|c|c|}
\hline & EC $\left(\mathbf{d S} \cdot \mathbf{m}^{-\mathbf{1}}\right)$ & $\mathbf{p H}$ & SAR \\
\hline Monsoon & 18.72 & 7.337 & 8.743 \\
\hline Winter & 42.51 & 7.043 & 18.963 \\
\hline Summer & 40.233 & 7.807 & 11.33 \\
\hline
\end{tabular}

\section{Location 3. Ganeshgadh}

Ganeshgadh is a freshwater location supporting typical plant species such as, Dichanthium annulatum, (Forssk.) stapf., Panicum colonum, L. and Schoenoplectus maritimus, Lye. Salinity in this habitat was quite low $\left(0.87\right.$ to $\left.2.64 \mathrm{dS} \cdot \mathrm{m}^{-1}\right)$ during different seasons and soil $\mathrm{pH}$ fluctuated from 7.76 to 8.29 (Table 3 ).

SAR values were noticed between 0.99 to 1.33 . Ionic concentration was also remarkably low and it showed greater amounts of $\mathrm{Cl}^{-}\left(0.34\right.$ to $\left.2.4 \mathrm{meq} \cdot \mathrm{g}^{-100}\right)$ than that of $\mathrm{Na}^{+}$ ( 0.35 to 0.71 meq. $\mathrm{g}^{-100}$ ) (Fig. 3 ). The $\mathrm{Mg}^{2+}$ content varying between 0.17 to 0.36 meq. $\mathrm{g}^{-100}$ was greater than that of $\mathrm{Ca}^{2+}\left(0.18\right.$ to $\left.0.20 \mathrm{meq} \cdot \mathrm{g}^{-100}\right)$. Low amounts of $\mathrm{K}^{+}$(0.02 to 0.07 $\left.\mathrm{meq} \cdot \mathrm{g}^{-100}\right)$ were noted. These findings primarily suggested marginal seasonal variations in physico-chemical characteristics and ionic content of a freshwater habitat.

Fig. 3. Ions in soil at ganesh gadh location.

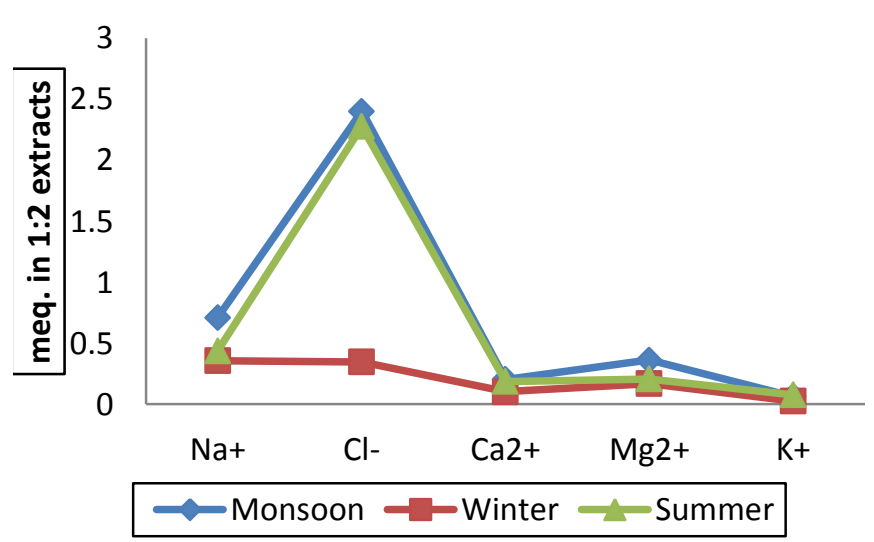

Table 3. Physico-chemical parameters at ganesh gadh location.

\begin{tabular}{|c|c|c|c|}
\hline & EC $\left(\mathbf{d S} \cdot \mathbf{m}^{-\mathbf{1}}\right)$ & $\mathbf{p H}$ & SAR \\
\hline Monsoon & 0.877 & 7.76 & 1.17 \\
\hline Winter & 2.64 & 7.63 & 1.337 \\
\hline Summer & 1.013 & 8.29 & 0.997 \\
\hline
\end{tabular}




\section{Location 4. Adhelai}

Adhelai represents a typical inland dry saline habitat. A succulent halophyte $S$. nudiflora, a less salt tolerant grass $D$. annulatum and a moderately salt tolerant shrub Prosopis chilensis, Stuntz. occupied this locality in 'Bhal' region.

Soil salinity fluctuated from 10.35 to $68.15 \mathrm{dS} \cdot \mathrm{m}^{-1}$ in different seasons (Table 4). $\mathrm{pH}$ and SAR varied from 7.40 to 7.73 and 2.74 to 4.50 , respectively.

Ionic composition showed greater values of $\mathrm{Na}^{+}\left(3.57\right.$ to $\left.12.2 \mathrm{meq} \cdot \mathrm{g}^{-100}\right)$ than that of $\mathrm{Cl}^{-}$(6.99 to $212.74 \mathrm{meq} \cdot \mathrm{g}^{-100}$ ) (Fig. 4).

$\mathrm{Ca}^{2+}$ and $\mathrm{Mg}^{2+}$ varied between 2.00 to $2.99 \mathrm{meq} \cdot \mathrm{g}^{-100}$ and 2.27 to $6.57 \mathrm{meq} \cdot \mathrm{g}^{-100}$. Low concentration of $\mathrm{K}^{+}\left(0.44\right.$ to $\left.0.82 \mathrm{meq} \cdot \mathrm{g}^{-100}\right)$ was observed here. Excluding the $\mathrm{Ca}^{2+}$ content and a couple of other exceptions, maximum values of all the soil characteristics were recorded in summer.

Fig. 4. Ions in soil at Adhelai location.

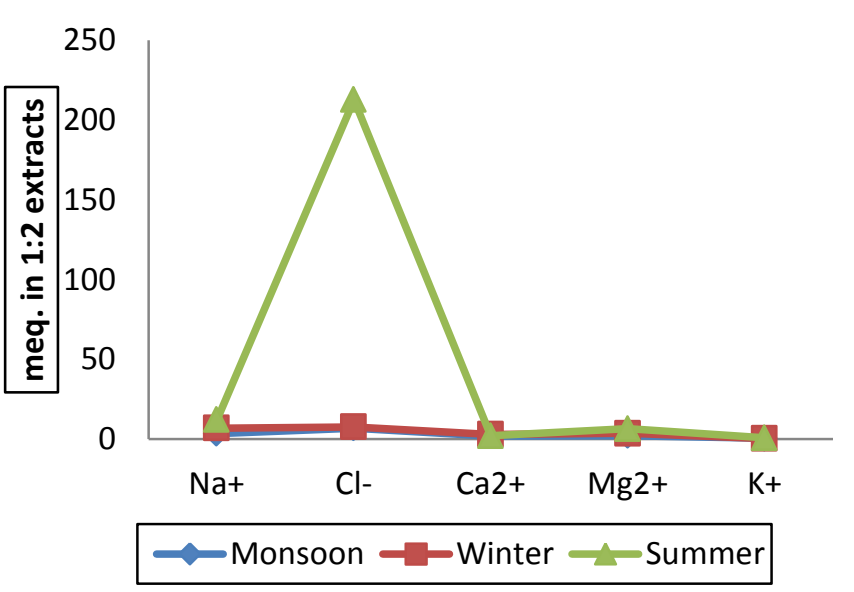

Table 4. Physico-chemical parameters at Adhelai location.

\begin{tabular}{|c|c|c|c|}
\hline & EC $\left(\mathbf{d S} \cdot \mathbf{m}^{-1}\right)$ & pH & SAR \\
\hline Monsoon & 19.533 & 7.403 & 2.74 \\
\hline Winter & 10.357 & 7.45 & 4.503 \\
\hline Summer & 68.15 & 7.733 & 6 \\
\hline
\end{tabular}

\section{Location 5. Velavadar}

As mentioned previously, this location is situated near Black Buck National Park and is mainly occupied by a grass Sporobolus coromandellianus, Link., Schoenoplectus maritimus, Lye. and Echinops echinatus, Roxb.

Analysis of soil samples collected from 3 belt transects laid down at this location indicated the electrical conductivity between 27.38 to $40.53 \mathrm{dS} \cdot \mathrm{m}^{-1}$ (Table 5). $\mathrm{pH}$ was observed between 6.95 to 7.45 and SAR from 8.87 to 12.48 . These findings further reflected dominance of $\mathrm{Na}^{+}$and $\mathrm{Cl} \cdot$ ranging between 6.10 to $22.56 \mathrm{meq} \cdot \mathrm{g}^{-100}$ and 15.89 to 37.58 meq $\cdot \mathrm{g}^{-100}$, respectively (Fig. 5). $\mathrm{Ca}^{2+}$ and $\mathrm{Mg}^{2+}$ varied between 0.29 to $7.24 \mathrm{meq} \cdot \mathrm{g}^{-100}$, while concentration of $\mathrm{K}^{+}$fluctuated between 0.42 to $1.01 \mathrm{meq} \cdot \mathrm{g}^{-100}$.

These results collectively reflected maximum values of $\mathrm{EC}, \mathrm{pH}, \mathrm{SAR}$ and all inorganic ions either in monsoon or summer. 
Fig. 5. Ions in soil at velavadar location.

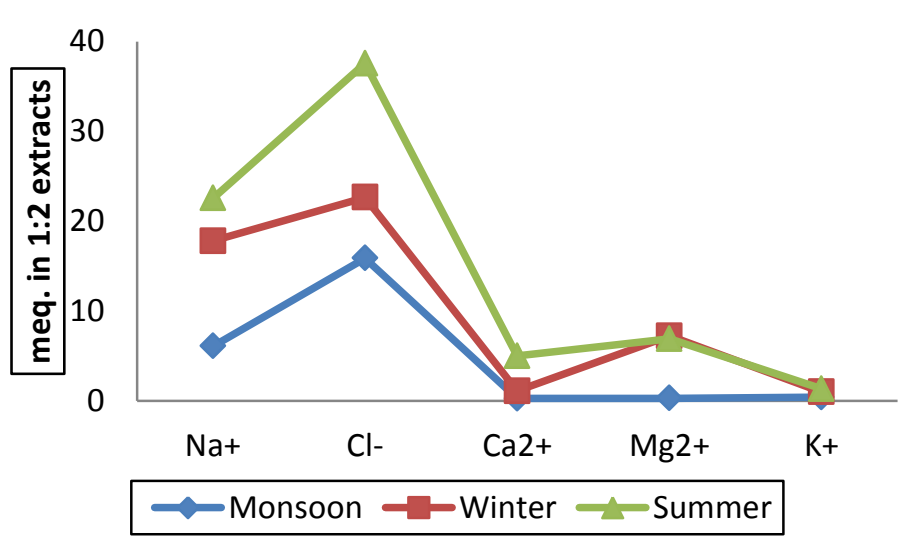

Table 5. Physico-chemical parameters at velavadar location.

\begin{tabular}{|c|c|c|c|}
\hline & EC $\left(\mathbf{d S} \cdot \mathbf{m}^{-\mathbf{1}}\right)$ & $\mathbf{p H}$ & SAR \\
\hline Monsoon & 40.533 & 6.953 & 12.48 \\
\hline Winter & 27.383 & 7.193 & 8.887 \\
\hline Summer & 28.6 & 7.457 & 9.467 \\
\hline
\end{tabular}

\section{DISCUSSION}

Although information on mangrove habitats is available in some publications (Blasco, 1975; Rao and Meher-Homji, 1985; Selvam et al., 1991; Dagar et al., 1993; Rao and Suresh, 2001), only few studies have been made on coastal habitats supporting remaining groups of plants mentioned in foregoing para. Earlier reports (Joshi and Iyengar, 1982; Kanzaria et al., 1982; and Hinglajia, 1997) include detailed analysis of coastal soils collected from some coastal localities.

\section{Salinity}

Findings of present study indicated that EC of (1:2) extracts of soil collected from 4 marshy or inland saline locations fluctuated between 10.35 to $68.15 \mathrm{dS} \cdot \mathrm{m}^{-1}$ (Tables 1 to $3 \&$ 5). Joshi (1982) and Rogel et al. $(1997,2001,2001 \mathrm{a})$ reported 10 to $216 \mathrm{dS} \cdot \mathrm{m}^{-1}$ salinity in the saturated extracts of soils supporting succulent halophytic vegetation, whereas Rao and Aggarwal (1964) recorded that total soluble salts in habitats of Suaeda nudiflora and Sesuvium portulacastrum were found between 2.04 to 3.4 per cent. Similarly, in his reviews, Dagar $(1995,1998)$ noted that pure patches of the same species grew on soils with 25.2 to $72.6 \mathrm{dS} \cdot \mathrm{m}^{-1} \mathrm{EC}_{\mathrm{e}}$ in inland areas of Rajasthan and Gujarat. Likewise, higher levels of salinity have also been observed for habitats of other shrubby halophytes (Joshi et al., 1993; Joshi and Hinglajia, 2000).

On the other hand, remarkably low salinity $\left(0.87\right.$ to $\left.2.64 \mathrm{dS} \cdot \mathrm{m}^{-1}\right)$ was noted for a freshwater site (Tables 3). It may be mentioned here that some of the coastal habitats supporting strand species Halopyrum mucronatum or even salt tolerant species like Suaeda fruticosa had such low levels of salinity (Khot, 2003).

\section{pH}

$\mathrm{pH}$ affects the physical conditions of soils, the nutrient availability to the plants and thereby growth of plants (Waisel, 1972; Chopra and Kanwar, 1980). Present investigation analyzing 45 soil samples showed that $\mathrm{pH}$ in natural habitats supporting aquatic, moderately salt tolerant and halophytic plant communities in 'Bhal' region varied from 6.95 to 8.29 (Tables 1 to 5). Earlier Joshi and Iyengar (1982) found Suaeda nudiflora and Salicornia 
brachiata growing on marshy soils with 7.4 to $8.3 \mathrm{pH}$. Other halophytic species, too, are known to grow in similar conditions of soil $\mathrm{pH}$ in different parts of the world (Sagar Kumar, 1987 and Rogel et al., 1997, 2001). A. lagopoides and S. nudiflora, too, grew in similar soil $\mathrm{pH}$ condition in 'Bhal' wetland.

Some reports examining relationship between soil $\mathrm{pH}$ and the zonations of halophytes indicated distribution or zonations of halophytes were not related to $\mathrm{pH}$ of natural habitats (Misra, 1989). However, Keith (1958) casually noted soil pH, as an important factor determining the distribution of halophytes.

It may be mentioned here that the present study showed that $\mathrm{pH}$ in marshy, freshwater and grassland habitats significantly differed in monsoon, winter and summer but no such effects were observed for 2 remaining habitats (Table 1 \& 3). These two important observations prompt a conclusion that coastal habitats subjected to similar climatic conditions may have different levels of $\mathrm{pH}$ possibly because of their geographical situation.

\section{SAR}

SAR values for 4 saline locations ranged between 2.74 to 18.96 and for a freshwater habitat between 0.99 to 1.33 (Tables 1 to 15). According to Waisel (1972), $\mathrm{Na}^{+}$brings about alterations in physicochemical properties of soils, when sodium adsorption ratio is 15 or more. Such interference was not observed for habitats in 'Bhal' area.

\section{Ionic Compositions}

Variations in ionic composition of soils suggested that $\mathrm{Na}^{+}$and $\mathrm{Cl}^{-}$were major constituents and their concentrations varied from 3.57 to $37.67 \mathrm{meq} \cdot \mathrm{g}^{-100}$ in saline habitats and between 0.35 to $0.71 \mathrm{meq} \cdot \mathrm{g}^{-100}$ in a freshwater habitat (Figs. 1 to 5). It was further observed that concentrations of $\mathrm{Cl}^{-}$were greater than that of $\mathrm{Na}^{+}$in all habitats. Rogel et al. (1997, 2001), too, noted similar trend for $\mathrm{Na}^{+}$and $\mathrm{Cl}^{-}$in habitats supporting Arthrocnemum macrostachyum and Sarcocornia fruticosa. Studies on coastal habitats in Gujarat having succulent and shrubby halophytes and strand species report such characteristic (Joshi and Iyenger, 1982; Joshi and Bhoite, 1988; Joshi and Hinglajia, 2000).

Observation on divalent cation reflected greater quantity of $\mathrm{Mg}^{2+}\left(0.32\right.$ to $9.51 \mathrm{meq} \cdot \mathrm{g}^{-}$ $\left.{ }^{100}\right)$ than that of $\mathrm{Ca}^{2+}\left(0.29\right.$ to $\left.4.25 \mathrm{meq} \cdot \mathrm{g}^{-100}\right)$ in habitats in 'Bhal' region.

Similar trend was observed for freshwater habitats, although concentrations of these two divalent cations were less than those recorded for other habitats. These findings are inconfirmatory with other reports on coastal locations occupied by divalent groups of coastal flora (Khot, 2003).

It may be added here that the $\mathrm{Mg}^{2+}$ content in 4 habitats fluctuated significantly (Table 1 to 5) but no such trend was observed for $\mathrm{Ca}^{2+}$. Likewise, a variation recorded for these 2 divalent cations were statistically non-significant. Saline and grassland habitats in 'Bhal' contain $\mathrm{K}^{+}$fluctuating between 0.36 to $3.05 \mathrm{meq} \cdot \mathrm{g}^{-100}$ whereas, its concentration in freshwater location ( 0.02 to $0.07 \mathrm{meq} \cdot \mathrm{g}^{-100}$ ) was comparatively low (Figs. 16 to 30$)$.

\section{CONCLUSIONS}

'Bhal' ecoregion, which is $\sim 100 \mathrm{~km}$ long and $\sim 25 \mathrm{~km}$ wide, is situated on the left border of Gulf of Khambhat in Gujarat. Average annual rainfall $(\sim 650 \mathrm{~mm})$; low temperature in winter $(\sim 100 \mathrm{C})$ and high in summer $(\sim 430 \mathrm{C})$; tidal inundation and freshwater flows in 
rivers make 'Bhal' as a unique coastal ecoregion. 5 locations in 'Bhal' area falling in the revenue district of Bhavnagar were selected for present investigation. Collection of soil samples were carried out in 3 seasons namely monsoon, winter and summer. Coastal vegetation of 'Bhal' region included 3 major groups of plants, namely highly salt tolerant halophytes, moderately salt tolerant species and aquatic plants. Analysis of 45 soil samples collected during 3 seasons from the selected locations indicated high values of electrical conductivity (salinity) and near neutral to alkaline $\mathrm{pH}$. Noticeable high concentrations of $\mathrm{Na}^{+}$ and $\mathrm{Cl}^{-}$followed by that $\mathrm{Ca}^{2+}, \mathrm{Mg}^{2+}$ and $\mathrm{K}^{+}$were observed in habitats. Salinity and amounts of mineral ions in freshwater habitat were remarkably low.

\section{References}

[1] Blasco F. (1975). The Mangroves of India. Institute Francais de Pondichery, India.

[2] Chopra S. L., Kanwar J. S. (1980). Analytical Agricultural Chemistry, Kalyani Publishers, New Delhi.

[3] Dagar J. C., A review. Inter. J. Ecol. and Environ. Sci. 21 (1995) 273-296.

[4] Dagar J. C., Singh N. T., Mongia A. D. (1993). Characteristics of mangrove soils and vegetation of Bay Islands in India. In: Towards the rational use of high salinity tolerant plants. (Lieth, H. and Al Masoom, A. edts.). 1, Kluwer Academic Publishers, The Netherlands, pp. 59-80.

[5] Hinglajia H. R. (1997). Physiological studies on salt tolerance in Prosopis juliflora (SW) DC., Ph. D. Thesis, Bhavnagar University, Bhavnagar.

[6] Joshi, A. J., Z. Pflanzen physiol 123 (1986) 497-502.

[7] Joshi A. J., Hinglajia H., Proc. Nat. Acad. Sci. India 70 (2000) 171-178.

[8] Joshi A. J., Iyengar E. R. R., Indian J. Mar. Sci. 11 (1982) 199-200.

[9] Joshi A. J., Krishnakumar M., Mali B. S., Ind. J. Plant Physiol. 34 (1993) 202-204.

[10] Kanzaria M. V., Patel M. S., Gundalia J. D., Patel C. L. (1982). Physico-chemical characteristics of salt affected soils of coastal belt of Saurashtra, Kutch and North Gujarat. Proc. of the Seminar on Mgmt. of Saline Alkaline Soils, Gujarat Agri. Uni., Junagadh. pp. 1-27.

[11] Khot S. S. (2003). Ecophysicological studies on some halophytes occurring in and around Marine National Park of India. Ph. D. Thesis, Bhavnagar University, Bhavnagar.

[12] Misra M. (1989). Studies on salt tolerance of Sporobolus madraspatanus Bor, a forage halophytic grass. Ph. D. Thesis, Bhavnagar Univ., Bhavnagar.

[13] Rao T. A., Aggarwal, K. R., Bull. Bot. Surv. India 6 (1964) 173-183.

[14] Rao T. A.,Meher-Homji V. M., Proc. Indian Acad. Sci. 9 (1985) 505-523.

[15] Rao T. A., Suresh P. V. (2001). Coastal ecosystems of the Karnataka State, India. I. Mangroves. Karnataka Association for the advancement of science, Banglore.

[16] Rogel J. A., Hernandez J., Silla R. O., Alcaraz F., Arid. Soil. Research and Re habilitation 11 (1997) 315-329. 
[17] Rogel J. A., Silla R. O., Ariza F. A.(a), Geoderma 99 (2001) 81-98.

[18] Rogel J. A., Silla R. O., Oro N. V. D., Ariza F. A., Catena 45 (2001) 73-84.

[19] Sagar Kumar A. (1987). Ecophysiological studies on coastal vegetation of Saurashtra coast. Ph. D. Thesis, Bhavnagar Univ., Bhavnagar.

[20] Selvam V., Mohan R., Ramasubramanian R., Azariah J., Indian J. Marine Sci. 20 (1991) 67-69.

[21] Vogl R. J., McHargue L. T., Ecology 47 (1966) 532-540.

[22] Waisel Y. (1972). Biology of Halophytes, Academic Press, New York. 